\begin{tabular}{ll}
\hline \hline MINING AND METALLURGY INSTITUTE BOR & ISSN: 2334-8836 \\
& UDK: 622 \\
\hline \hline
\end{tabular}

\title{
DEPENDENCE OF THE BOND WORK INDEX OF GRINDABILITY ON GRAIN-SIZE DISTRIBUTION OF THE STARTING SAMPLE OF SIZE CLASS -3.35 mm $^{* * * *}$
}

\begin{abstract}
The research results of the effect of grain-size distribution of the starting sample of size class $-3.35 \mathrm{~mm}$ on the value of the Bond work index OF grindability, obtained by the method of shortened procedure by prof. N. Magdalinovic, clearly indicate that the characteristics of starting sample significantly affects the value of resistance to comminution.

Differences in values of the Bond work index of grindability for low-grade copper ore of $5.4 \mathrm{kWh} / \mathrm{tor}$ about $42 \%$ and high-grade copper ore of $3.77 \mathrm{kWh} / \mathrm{t}$ or about $35 \%$, from the point of the theory of comminution and practical application in designing and selection of process equipment are of particular importance.
\end{abstract}

Keywords: copper ore, Bond index, grindability, grain-size distribution, coefficient of line direction.

\section{INTRODUCTION}

Research whose results are presented in a paper [Stanojlović et al., 2013] show that high difference in grain-size distribution of definitive product of crushing for various copper ores affects the grain-size distribution of the starting sample of size class $-3.35 \mathrm{~mm}$ for determining the Bond work index of grindability. It was also found that naturally higher resistance, low-grade copper ore, due to various conditions, in blasting, mining, industrial processing of raw materials to the laboratory sample preparation, can cause finest grainsize distribution of the starting sample of size class $-3.35 \mathrm{~mm}$, and lower value of the Bond work index of grindability, which is contrary to the theory of comminution. Misleading information about resistance mate-

\footnotetext{
*University of Belgrade, Technical Faculty in Bor, Vojske Jugoslavije 12, 19210, Bor, Serbia, e-mail:rstanojlovic@tf.bor.ac.rs

*** RTB Bor, Djordja Vajferta 29, 19210 Bor, Serbia

**** This paper presents the results of the Projects TR 33007 "Implementation of Modern TechnicalTechnological and Environmental Solutions in the Existing Production Systems of the Copper Mine Bor and Copper Mine Majdanpek" and TR 33038 "Improving Technology of Exploitation and Processing of Copper Ore with Monitoring the Living and Working Environment in the RTB Bor Group", funded by the Ministry of Education, Science and Technological Development of the Republic of Serbia. The authors are grateful to the Ministry for financial support.
} 
rials to comminution have negative effects on technological design of grinding process and selection of process equipment, as well as the efficiency of industrial plants.

In accordance with the previous conclusions, the research in this paper will be focused on defining the effect of grain sizedistribution of the starting sample of size class $-3.35 \mathrm{~mm}$, on value of the Bond work index of grindability of low-grade and highgrade copper ore from the Copper Mine Bor, Serbia. Studies were conducted on the synthetic starting samples formed for determining the Bond work index of grindability of size class $-3.35 \mathrm{~mm}$, both tested materials.

\section{EXPERIMENTAL}

\subsection{Material}

Tested samples are the final industrial crushing products of low-grade and highgrade copper ore from the Copper Mine Bor, with the upper limit of size class of $35 \mathrm{~mm}$. Copper ore was mined from the underground mine Jama in Bor that has the significant reserves of low-grade copper ore with the average copper content of about 0.95 to $1.00 \%$, and small reserves of high-grade copper ore, several hundred thousand tons, with the average copper content of 2 to $5 \%$, gold 1-3 g/t and silver from 2.7 to $7.23 \mathrm{~g} / \mathrm{t}$, which are in the process of exploitation. Samples of low-grade and high-grade copper ore were crushed to the upper limit size class of $3.35 \mathrm{~mm}$ using the standard procedure in a laboratory jaw crusher and which were prepared for determining the Bond work index of grindability.

The grain-size distribution was determined on prepared samples of low-grade and high-grade copper ore and samples were separated for determining the Bond work index of grindability. Synthetic starting samples were formed from the same samples with different grain-size distribution on which the Bond work index of grindability was also determined. The samples were formed using the Gaudin-Schumann equation. At selected value of the coefficient of the line direction, $\mathrm{m}$, from the grain size cumulative curves, the partial participation of narrow size class was determined for all synthetic sample separately.

\subsection{Equipment and Methods}

Grain-size distributions of all samples, that were the subject matter, were determined by sieve analysis of dry method on laboratory Tyler sieve series of selected sizes.

The sieving experiments were performed using a mechanical vibratory sieve shaker, type "Retsch", with specific frequency.

Determining the Bond work index of grindability was performed in the Bond' ball mill by dry grinding process [Bond, 1949; $1952 ; 1961]$. As the method for determining the Bond' work index of grindability, the shortened procedure by prof. N. Magdalinović [Magdalinović, 1989] was used.

\section{RESULTS AND DISCUSSION}

\subsection{Grain-size Distribution of Low- grade and High-grade Copper Ore}

The samples of final product of industrial crushing, the upper limit of size $35 \mathrm{~mm}$, as well as prepared samples of size class $-3.35 \mathrm{~mm}$ for determining the Bond work index, were sieved by dry method on selected series of standard sieves and test results are presented on diagrams in Figures 1 and 2. 


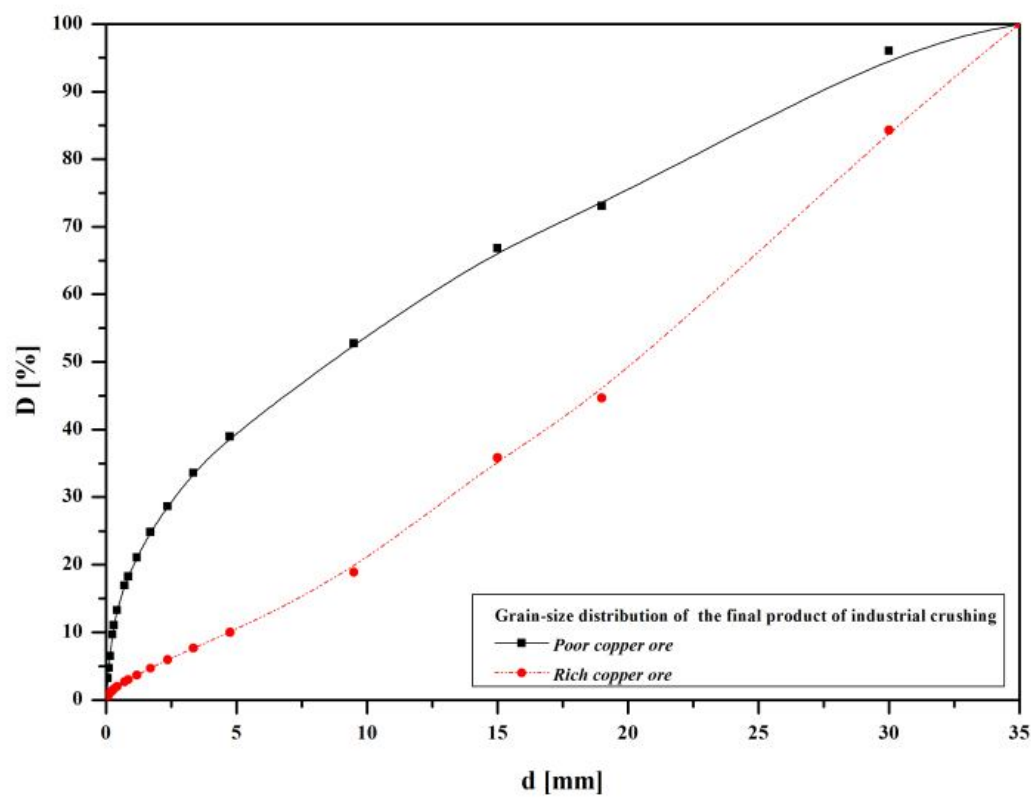

Figure 1 Grain-size distribution of the final crushing products of low-grade and high-grade copper ore

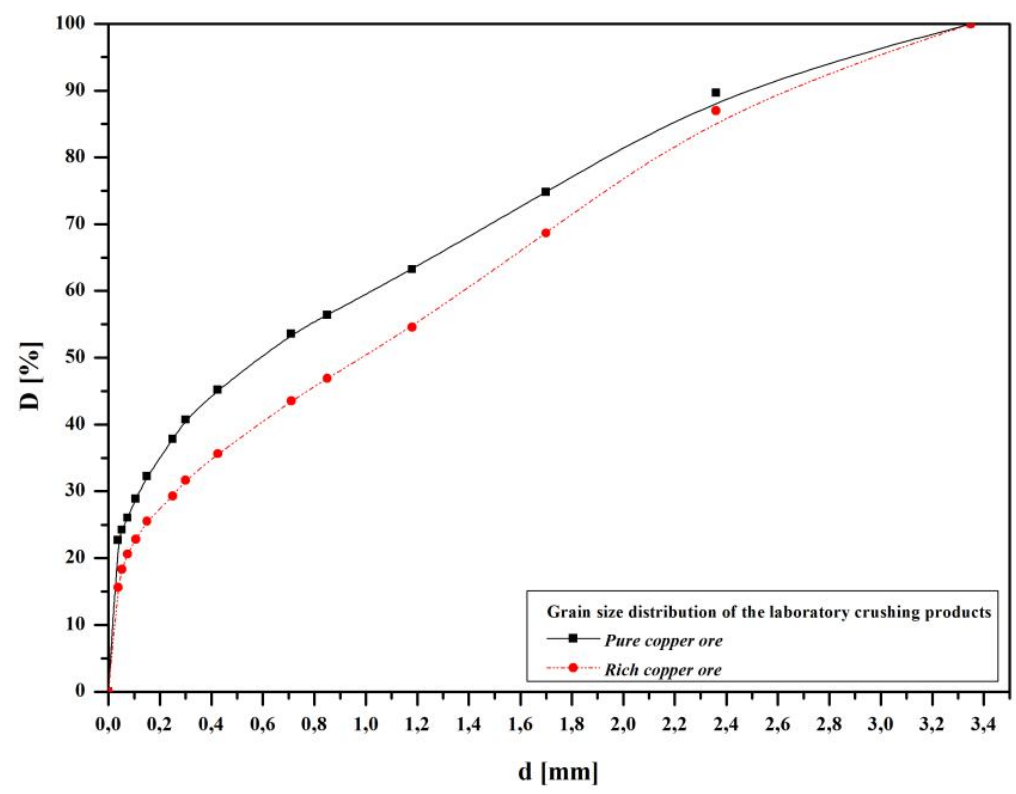

Figure 2 Grain-size distributions of the starting samples of size class - $3.35 \mathrm{~mm}$ for determining the Bond work index of grindability 
Test results [Stanojlović et al., 2013] show a significant difference in the grainsize distribution of the final crushing products, Figure 1, as well as the prepared samples of size class $-3.35 \mathrm{~mm}$ for determining the Bond work index, Figure 2. The difference in grain size characteristics will be shown through the coefficient of line direction, $\mathrm{m}$, of the grain-size distribution of cumulative curves, defined using the GaudinSchumann equation:

$$
\mathrm{D}=100\left(\mathrm{~d} / \mathrm{d}_{\max }\right)^{\mathrm{m}}(\%)
$$

where:

D - Cumulative passing values (\%)

$\mathrm{d}$ - sieve opening (mm)

$\mathrm{D}_{\max }$-upper limit size of sample (mm)

$\mathrm{m}$ - coefficient of the line direction of the grain size distribution

Coefficient of the line direction of the grain size distribution for the final crushing product of low-grade copper ore has value $\mathrm{m}=0.5$, while the value of same parameter for high-grade copper ore is $\mathrm{m}=1.2$.

The prepared, starting samples of size class $-3,35 \mathrm{~mm}$ for the determination of the Bond's work index grindability of the poor and rich copper ore have the different grain size distribution. Coefficient of the line direction of grain size cumulutive curves of low-grade copper ore is $\mathrm{m}=0.4$, while the same parameter for high-grade copper ore is $\mathrm{m}=0.5$.

It can be concluded from diagrams shown in Figures 1 and 2 that the samples of low-grade copper ore are the finest compared to the samples of high-grade copper ore products, which could lead to the conclusion of lesser resistance to comminution of low-grade compared to high-grade copper ore. This hypothesis is in contrast to the previous theoretical and practical knowledge of these raw mate- rials, which was the main motive for further research.

\subsection{Bond's Work Index of Grindability the Low-grade and High-grade Copper Ore}

Bond's theory of comminution is widely accepted in the theory and practice of comminution process of raw material. According to this, the comminution energy is defined using the relation:

$$
W=W_{i} \cdot\left(\frac{10}{\sqrt{P}}-\frac{10}{\sqrt{F}}\right),(\mathrm{kWh} / \mathrm{t})
$$

where:

$\mathrm{W}$ - specific energy consumption $(\mathrm{kWh} / \mathrm{t})$

$\mathrm{W}_{i}$ - Bond work index, $(\mathrm{kWh} / \mathrm{t})$

$\mathrm{F}$ - feed $80 \%$ passing size, $(\mu \mathrm{m})$

$\mathrm{P}$ - product $80 \%$ passing size, $(\mu \mathrm{m})$.

The Bond work index $\left(\mathrm{W}_{i}\right)$, is a material constant which is determined by laboratory testing procedure and in the ball mill, defined by F. C. Bond [Bond, 1949, 1952, 1961]. For determining the Bond work index of grindability, the shortened procedure prof. N. Magdalinović [Magdalinović, 1985, 1989] was used in this work.

\subsection{The Effect of Grain-size Distribution of the Starting Sample of size class $-3.35 \mathrm{~mm}$, on Value of the Bond Work Index of Grindability}

Using the equation (1) with the given parameter values, $\mathrm{m}(\mathrm{m}=0,2 ; 0,4 ; 0,6$; $0,8 ; 1,0)$, the grain-size distributions of synthetic formed starting samples of lowgrade and high-grade copper are determined for determining the Bond work index of grindability. The cumulative and partial passing values of certain size class for formation the synthetic samples are given in Table 1, and the grainsize distribution curves of the same samples are shown on diagrams in Figure 3. 
Table 1 Grain size distribution of synthetic starting samples of low-grade and high-grade copper ore

\begin{tabular}{|c|c|c|c|c|c|}
\hline \multirow{3}{*}{$\begin{array}{c}\text { Grain size fraction } \\
\qquad \mathrm{d}(\mathrm{mm})\end{array}$} & \multicolumn{5}{|c|}{$\mathbf{m}$} \\
\hline & 0.2 & 0.4 & 0.6 & 0.8 & 1.0 \\
\hline & \multicolumn{5}{|c|}{ Cumulative passing values $\mathrm{D}=100\left(\mathrm{~d} / \mathrm{d}_{\max }\right)^{\mathrm{m}}(\%)$} \\
\hline$-3.350+1.700$ & 100.00 & 100.00 & 100.00 & 100.00 & 100.00 \\
\hline$-1.700+0.850$ & 87.31 & 76.24 & 66.56 & 58.12 & 50.75 \\
\hline$-0.850+0.425$ & 76.01 & 57.78 & 43.92 & 33.38 & 25.37 \\
\hline$-0.425+0.150$ & 66.17 & 43.79 & 28.97 & 19.17 & 12.69 \\
\hline$-0.150+0.106$ & 53.73 & 28.87 & 15.51 & 8.33 & 4.48 \\
\hline$-0.106+0.075$ & 50.12 & 25.12 & 12.59 & 6.31 & 3.16 \\
\hline$-0.075+0$ & 46.77 & 21.88 & 10.23 & 4.79 & 2.24 \\
\hline $\begin{array}{c}\text { Grain size fraction } \\
\text { d (mm) }\end{array}$ & \multicolumn{5}{|c|}{ Partial passing values $W(\%)$} \\
\hline$-3.350+1.700$ & 12.69 & 23.76 & 33.44 & 41.88 & 49.25 \\
\hline$-1.700+0.850$ & 11.30 & 18.46 & 22.65 & 24.74 & 25.37 \\
\hline$-0.850+0.425$ & 9.84 & 13.99 & 14.94 & 14.21 & 12.69 \\
\hline$-0.425+0.150$ & 12.45 & 14.92 & 13.46 & 10.84 & 8.21 \\
\hline$-0.150+0.106$ & 3.60 & 3.74 & 2.92 & 2.02 & 1.31 \\
\hline$-0.106+0.075$ & 3.35 & 3.25 & 2.36 & 1.52 & 0.93 \\
\hline$-0.075+0$ & 46.77 & 21.88 & 10.23 & 4.79 & 2.24 \\
\hline
\end{tabular}

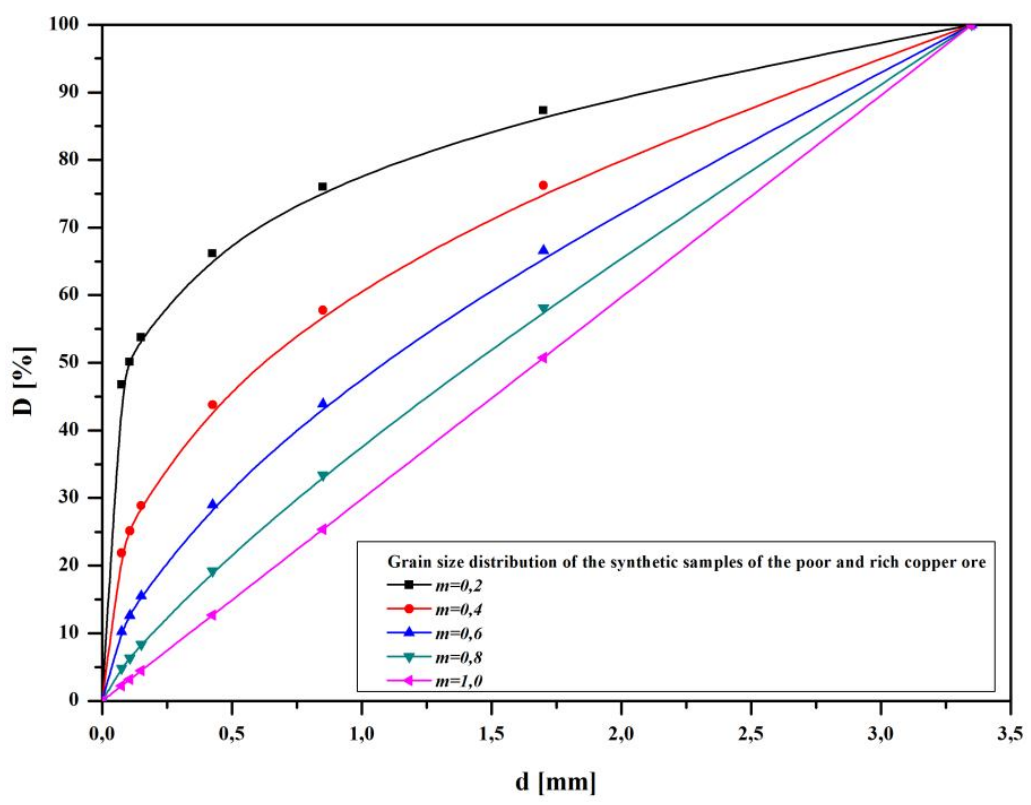

Figure 3 Grain-size distribution curves of synthetic starting samples of low-grade and high-grade copper ore 
Test results of the Bond work index of grindability using the shortened procedure by prof. N. Magdalinović, formed on synthetic starting samples of low-grade cop per ore are shown in Table 2, and the obtained data on the same synthetic samples of high-grade copper ore are given in Table 3.

Table 2 Bond's work index of grindability of low-grade copper ore in the function of parameter $m$

\begin{tabular}{|c|r|r|r|r|r|}
\hline \multirow{2}{*}{ Parameters } & \multicolumn{6}{|c|}{$\mathbf{m}$} \\
\cline { 2 - 6 } & \multicolumn{1}{|c|}{$\mathbf{0 . 2}$} & \multicolumn{1}{|c|}{$\mathbf{0 . 4}$} & \multicolumn{1}{c|}{$\mathbf{0 . 6}$} & \multicolumn{1}{c|}{$\mathbf{0 . 8}$} & \multicolumn{1}{c|}{$\mathbf{1 . 0}$} \\
\hline Pc $(\boldsymbol{\mu m})$ & 106.00 & 106.00 & 106.00 & 106.00 & 106.00 \\
\hline $\mathbf{G}(\mathbf{g})$ & 1.60 & 1.32 & 1.13 & 1.07 & 1.16 \\
\hline $\mathbf{P}(\boldsymbol{\mu m})$ & 69.8 & 82.8 & 83.1 & 86.0 & 75.0 \\
\hline $\mathbf{F}(\boldsymbol{\mu m})$ & 1172.2 & 2008.9 & 2373.8 & 2560.7 & 2677.6 \\
\hline $\mathbf{W i}(\mathbf{k W h} / \mathbf{t})$ & $\mathbf{1 2 . 5 9}$ & $\mathbf{1 5 . 2 4}$ & $\mathbf{1 7 . 0 1}$ & $\mathbf{1 7 . 9 9}$ & $\mathbf{1 5 . 4 7}$ \\
\hline
\end{tabular}

Table 3 Bond's work index of grindability of high-grade copper in the function of parameter $m$

\begin{tabular}{|c|r|r|r|r|r|}
\hline \multirow{2}{*}{ Parameters } & \multicolumn{5}{|c|}{$\mathbf{m}$} \\
\cline { 2 - 6 } & \multicolumn{1}{|c|}{$\mathbf{0 . 2}$} & \multicolumn{1}{|c|}{$\mathbf{0 . 4}$} & \multicolumn{1}{c|}{$\mathbf{0 . 6}$} & \multicolumn{1}{c|}{$\mathbf{0 . 8}$} & \multicolumn{1}{c|}{$\mathbf{1 . 0}$} \\
\hline Pc $(\boldsymbol{\mu m})$ & 106.00 & 106.00 & 106.00 & 106.00 & 106.00 \\
\hline $\mathbf{G}(\mathbf{g})$ & 2.09 & 1.72 & 1.44 & 1.30 & 1.64 \\
\hline $\mathbf{P}(\boldsymbol{\mu m})$ & 76.0 & 77.0 & 78.5 & 78.5 & 77.0 \\
\hline $\mathbf{F}(\boldsymbol{\mu m})$ & 1172.2 & 2008.9 & 2373.8 & 2677.6 & 2560.7 \\
\hline $\mathbf{W i}(\mathbf{k W h} / \mathbf{t})$ & $\mathbf{1 0 . 7 0}$ & $\mathbf{1 1 . 7 1}$ & $\mathbf{1 3 . 4 8}$ & $\mathbf{1 4 . 4 7}$ & $\mathbf{1 1 . 8 3}$ \\
\hline
\end{tabular}

The obtained values of the Bond work index grindability, for low-grade, as well as high-grade copper ore, clearly indicate that grain-size distribution of the starting sample of size class $-3.35 \mathrm{~mm}$ defined by the coefficient of line direction, $m$, affects the value of resistance to comminution.

Differences in values of the Bond work index of grindability, for low-grade copper ore, $5.4 \mathrm{kWh} / \mathrm{t}$, and for high-grade copper ore, $3.77 \mathrm{kWh} / \mathrm{t}$, from the aspect of comminution theory as well as the practical application are respectable and should be considered.

All tests confirm that the same grain-size distribution of the starting sample of size class $-3,35 \mathrm{~mm}$ for determining the Bond work index, low-grade copper ore have higher value of resistance to comminution compared to high-grade copper ore, what is in accordance with the current, both theoretical and practical experience in these raw materials.

\subsection{Dependence of the Bond Work Index of Grindability on Coefficient of Line Direction, $m$, for the Starting Sample of Size Class - 3.35 mm}

The research results on synthetic samples of low-grade and high-grade copper ore of size class $-3.35 \mathrm{~mm}$, are shown on diagram in Figure 4. 


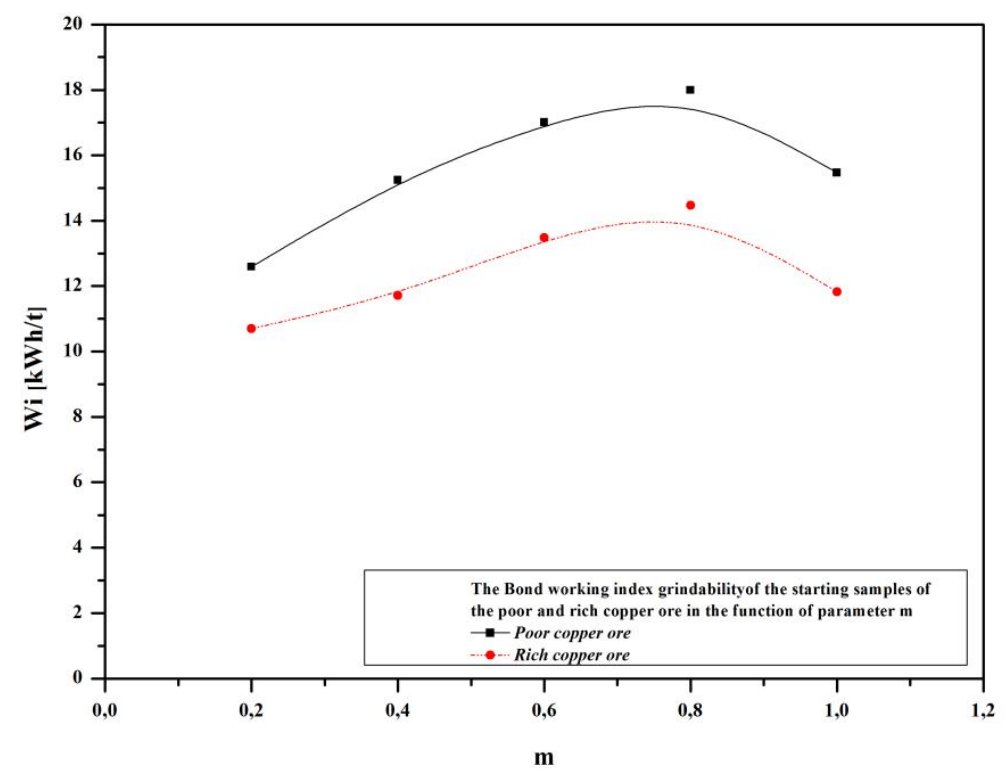

Figure 4 Dependence of the Bond work index of grindability on coefficient of line direction of grain-size distribution, $m$, the starting sample of size class $-3.35 \mathrm{~mm}$

Two facts can be stated by analysis of these results. All values of the Bond work index of grindability of low-grade copper ore were higher than the same parameter for high-grade copper ore with the same grain-size distribution characteristics. It also confirms dependence of the Bond work index on grain-size distribution of the starting sample of size class $-3.35 \mathrm{~mm}$, represented by the coefficient of line direction, $\mathrm{m}$, of the grain-size distribution curve.

The functional dependence of these indicators for low-grade and high-grade copper ore has a similar trend.

\section{CONCLUSION}

The shape and form of occurrence in deposit, blasting and mining method as well as primary comminution of raw materials under different conditions can cause that raw materials, more resistant to comminution, have finest grain-size distribution compared to raw material with lower resistance.
Relatively selective comminution of raw materials in a laboratory crushers in the preparation of samples of size class -3.35 $\mathrm{mm}$, for determining the Bond work index of grindability, this phenomenon cannot be changed, so the starting sample for determining the parameters of resistance to comminution has an inadequate grain-size distribution. Research on low-grade and high-grade copper ore from the Copper Mine Bor has confirmed this statement.

Research of the Bond work index of grindability on low-grade and high-grade copper ore using the method of shortened procedure by prof. N. Magdalinović [Magdalinović, 1989] (Table 2 and the 3), indicate that grain-size distribution of the starting sample $-3.35 \mathrm{~mm}$, affects the value of this parameter of grindability. Dependence of the Bond work index of grindability compared to grain-size distribution of the starting sample, represented by the coefficient of line direction, $m$, is shown on diagram in Figure 4. Diffe- 


\section{REFERENCES}

rences in values of the Bond work index of grindability, for low-grade copper ore, $5.4 \mathrm{kWh} / \mathrm{t}$ or approximately $42 \%$, compared to high-grade copper ore, 3.77 $\mathrm{kWh} / \mathrm{t}$ or approximately $35 \%$, from the point of both, theory and practical application are respectable and should be considered.

All tests confirm that with the identical grain-size distributions, identical coefficients of the line directions, $m$, of the starting samples of size class $-3.35 \mathrm{~mm}$, which are used for determining the Bond work index of grindability, low-grade copper ores have higher resistant to comminution compared to the same parameters of high-grade copper ore.

The functional dependence of the Bond work index of grindability of coefficients of the line directions, $\mathrm{m}$, for lowgrade and high-grade copper ore have similar trend. In future, research on several different raw materials will consider the possibility of defining a model of mentioned functional dependencies.
[1] Stanojlović R., Sokolović J., Stančev N., Granulometric Composition of Starting Samples of Size class - 3.35 mm - the Reliability Factor of Bond Working Index of Grindability, Mining Engineering, 1 (2013), pp. 161-170.

[2] Magdalinović N., Comminution and Classification of Minerals, Practical (In Serbian), Technical Faculty in Bor, Bor, 1985.

[3] Magdalinović, N., A Procedure for Rapid Determination of the Bond Work Index, International Journal of Mineral Processing, 27 (1-2) (1989), pp. 125-132.

[4] Magdalinović N., Energy of Comminution, (In Serbian), Technical Faculty in Bor, Bor, 1992.

[5] Bond, F.C., Standard Grindability Test Tabulated, Trans. Am. Inst. Min. Eng., 183 (1949), pp. 313-329.

[6] Bond. F.C., The Third Theory of Communition, Trans. Am. Inst. Min. Eng., 193, (1952), pp. 484-494.

[7] Bond, F.C., Crushing and Grinding Calculations Part I and II, British Chemical Engineering 6 (6 and 8), 1961. 


\begin{tabular}{ll}
\hline \hline INSTITUT ZA RUDARSTVO I METALURGIJU BOR & ISSN: 2334-8836 \\
& UDK: 622 \\
\hline \hline
\end{tabular}

Rodoljub Stanojlović, Jovica Sokolović, Nikola Stančev ${ }^{\text {** }}$

\section{ZAVISNOST BOND-OVOG RADNOG INDEKSA MELJIVOSTI OD GRANULOMETRIJSKOG SASTAVA POČETNOG UZORKA KLASE KRUPNOĆE - 3,35 mm***}

Izvod

Rezultati istraživanja uticaja granulometrijskog sastava početnog uzorka klase krupnoće - 3,35 mm na vrednost Bond-ovog radnog indeksa meljivosti, definisanog primenom metode skraćenog postupka prof. Magdalinović, nedvosmisleno upućuju na zaključak da ova karakteristika početnog uzorka značajno utiče na vrednost pokazatelja otpornosti prema usitnjavanju.

Razlike u vrednostima Bond-ovog radnog indeksa meljivosti, za siromašnu rudu bakra od 5,4 kWh/t, odnosno oko $42 \%$ i bogatu rudu bakra, od 3,77 kWh/t, odnosno oko $35 \%$, su sa stanovišta kako teorije usitnjavanja tako i praktične primene u projektovanju i izboru procesne opreme od posebnog značaja.

Ključne reči: ruda bakra, Bond, indeks meljivosti, granulometrsijski sastav, koeficijent pravca prave.

\section{UVOD}

Istraživanja čiji su rezultati prezentovani u radu [Stanojlović i dr., 2013], pokazuju da velika razlika u granulometrijskim sastavima definitivnih proizvoda drobljenja različitih ruda bakra utiče na granulometrijski sastav polaznog uzorka klase krupnoće - 3,35 mm za određivanje Bond-ovog radnog indeksa meljivosti. Takođe je konstatovano da prirodno otpornija, siromašna ruda bakra, zbog različitih uslova, pri miniranju, eksploataciji, industrijskoj preradi sirovine do laboratorijske pripreme uzorka, može usloviti finozrniji granulometrijski sastav polaznog uzorka klase krupnoće - 3,35 mm, a isti manju vrednost Bond-ovog radnog indeksa meljivosti, što je u suprotnosti sa teorijom usitnjavanja. Pogrešne informacije o otpornosti sirovina na usitnjavanje imaju negativne posledice kako na projektovanje

\footnotetext{
*Univerzitet u Beogradu, Tehnički fakultet u Boru, Vojske Jugoslavije 12, 19210, Bor, Srbija, e-mail: rstanojlovic@tf.bor.ac.rs

${ }^{* *}$ RTB Bor, Đorđa Vajferta 29, 19210 Bor, Srbija

${ }^{* * * *}$ U ovom radu su prikazani rezultati projekata TR 33007 „Implementacija savremenijih tehničkotehnoloških i ekoloških rešenja u postojećim proizvodnim sistemima Rudnika bakra Bor i Rudnika bakra Majdanpek“ $i$ TR 33038 „Usavršavanje tehnologija eksploatacije i prerade rude bakra sa monitoringom životne $i$ radne sredine u RTB Bor Grupa" finansiranih od strane Ministarstva prosvete, nauke i tehnološkog razvoja Republike Srbije. Autori se zahvaljuju pomenutom Ministarstvu na finansijskoj podršci.
} 
tehnoloških procesa usitnjavanja i izbor procesne opreme, tako i na efikasnost rada industrijskih postrojenja.

Shodno predhodnim konstatacijama istraživanja $u$ ovom radu biće usmerena $u$ pravcu definisanja uticaja granulometrijskog sastava polaznog uzorka klase krupnoće - 3,35 mm, na vrednost Bond-ovog radnog indeksa meljivosti siromašne i bogate rude bakra RB Bor, Srbija. Istraživanja su vršena na sintetički formiranim polaznim uzorcima za definisanje Bond-ovog radnog indeksa meljivosti, klase krupnoće - 3,35 mm, obe ispitivane sirovine.

\section{EKSPERIMENTALNI DEO}

\subsection{Materijal}

Uzorci na kojima su vršena istraživanja su definitivni, industrijski proizvodi drobljenja siromašne i bogate rude bakra RB Bor, gornje granične krupnoće - $35 \mathrm{~mm}$. Rude bakra su eksploatisane iz Jame Rudnika Bor, koja raspolaže sa značajnim rezervama siromašne rude sa sadržajem bakra oko 0,95$1,00 \%$, i manjim rezervama, nekoliko stotina hiljada tona u fazi eksploatacije, bogate rude sa sadržajem bakra od 2-5 \%, zlata 1-3 g/t i srebra od 2,7-7,23 g/t. Standardnom procedurom u laboratorijskoj čeljusnoj drobilici uzorci siromašne i bogate rude bakra su usitnjeni do gornje graniče krupnoće 3,35 $\mathrm{mm}$, čime su pripremljeni za određivanje Bond-ovog radnog indeksa meljivosti.

$\mathrm{Na}$ ovako pripremljenim uzorcima siromašne i bogate rude bakra određeni su granulometrijski sastavi i izdvojeni uzorci za određivanje Bond-ovog radnog indeksa meljivosti. Od istih uzoraka formirani su sintetički polazni uzorci različitih granulo- metrijskih sastava na kojima je takođe određivan Bond-ov radni indeks meljivosti. Uzorci su formirani tako što je primenom Gaudin-Schumannove jednačine, pri odabranim vrednostima koeficijenta pravca krivih granulometrijskih sastava, $\mathrm{m}$, definisano parcijalno učešće uskih klasa krupnoće za svaki sintetički uzorak posebno.

\subsection{Oprema i postupci}

Granulometrijski sastavi svih uzoraka koji su bili predmet ispitivanja određeni su sitovnim analizama suvim postupkom na laboratorijskim sitima odabrane veličine otvora, serije Tyler.

Opiti prosejavanja izvođeni su primenom mehaničkog vibracionog uređaja tipa Retsch određene frekvence.

Određivanje Bond-ovog radnog indeksa meljivosti vršeno je u Bond-ovom mlinu sa kuglama, postupkom suvog mlevenja [Bond, 1949; 1952; 1961]. Kao metod za određivanje Bond-ovog radnog indeksa meljivosti korišćen je skraćeni postupak prof. N. Magdalinovića [Magdalinović, 1989].

\section{REZULTATI I DISKUSIJA}

\subsection{Granulometrijski sastavi siromašne i bogate rude bakra}

Uzorci definitivnih proizvoda drobljenja gornje granične krupnoće $35 \mathrm{~mm}$, i pripremljeni uzorci klase krupnoće -3,35 $\mathrm{mm}$, za određivanje Bond-ovog radnog indeksa, prosejani su suvim postupkom na odabranim serijama sita, a rezultati ispitivanja prezentovani dijagramima na slikama 1 i 2. 


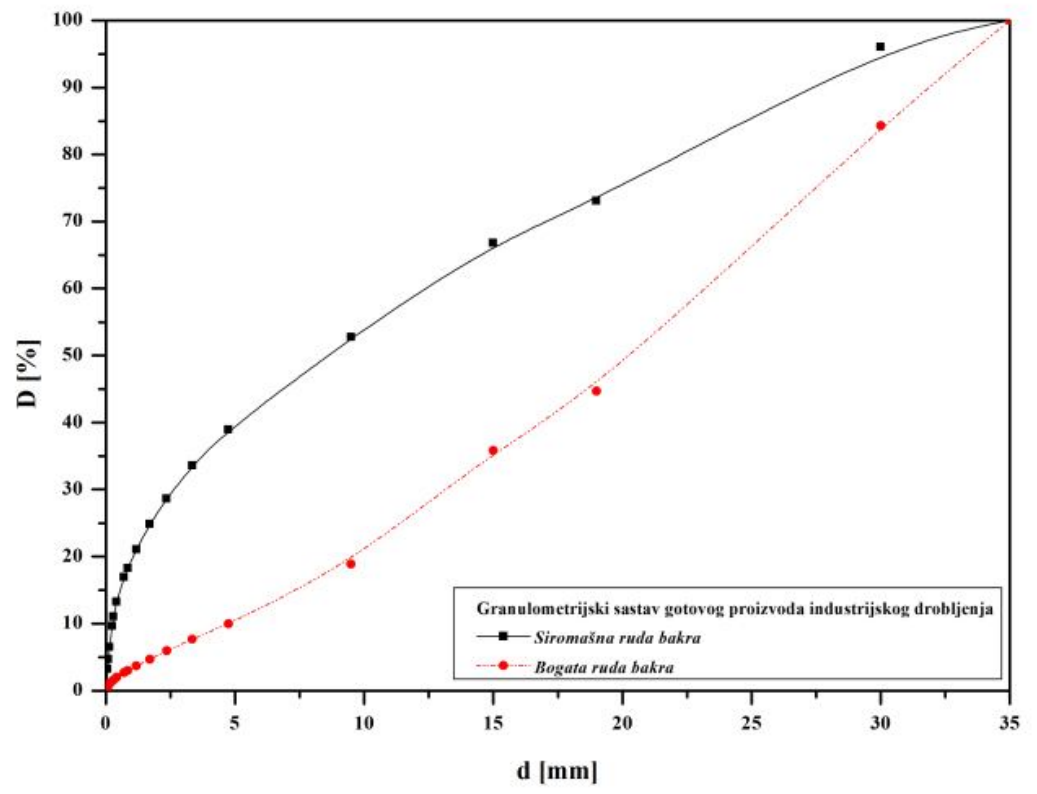

SI. 1. Granulometrijski sastavi definitivnih proizvoda drobljenja siromašne i bogate rude bakra

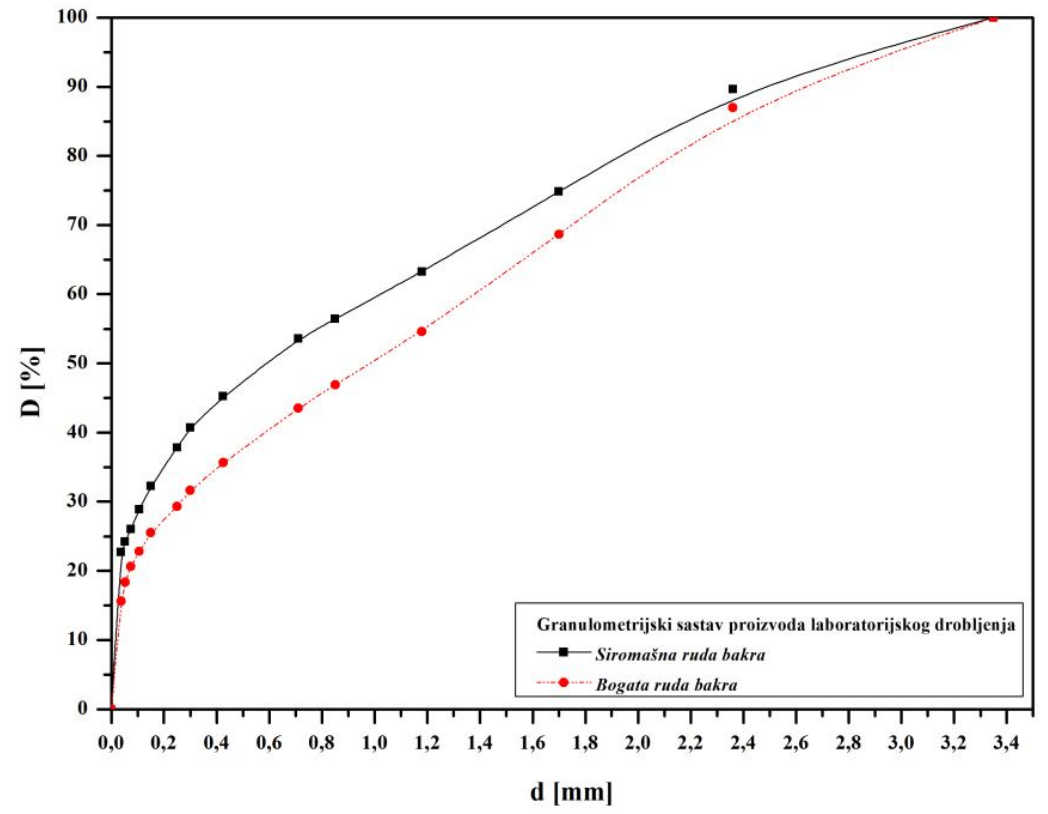

S1. 2. Granulometrijski sastavi početnih uzoraka klase - 3,35 $\mathrm{mm}$ za određivanje Bond-ovog radnog indeksa meljivosti 


\subsection{Bond-ov radni indeks meljivosti siromašne i bogate rude bakra}

Rezultati ispitivanja [Stanojlović i dr., 2013] pokazuju veliku razliku u granulometrijskim sastavima kako definitivnih proizvoda drobljenja, slika 1, tako i pripremljenih uzoraka klase krupnoće - 3,35 mm za određivanje Bond-ovog radnog indeksa, slika 2. Razliku u granulometrijskim karakteristikama prikazaćemo preko koeficijenta pravca krivih granulometrijskih sastava, definisanih primenom jednačine GaudinSchumanna:

$$
\mathrm{D}=100\left(\mathrm{~d} / \mathrm{d}_{\max }\right)^{\mathrm{m}}(\%)
$$

gde su:

D - kumulativni prosev (\%)

d - otvor sita (mm)

$\mathrm{d}_{\max }$ - gornja granična krupnoća uzorka (mm)

m - koeficijent pravca krive granulometrijskog sastava

Koeficijent pravca krive granulometrijskog sastava definitivnog proizvoda drobljenja siromašne rude bakra ima vrednost $\mathrm{m}=0,5$, dok je vrednost istog parametra za bogatu rudu $\mathrm{m}=1,2$.

Pripremljeni polazni uzorci, klase krupnoće - 3,35 mm, za određivanje Bond-ovog radnog indeksa meljivosti siromašne $\mathrm{i}$ bogate rude bakra, takođe su različitih granulometrijskih sastava. Koeficijent pravca krive granulometrijskog sastava siromašne rude je $\mathrm{m}=0,4$, dok je isti parametar za bogatu rudu $\mathrm{m}=0,5$.

Sa dijagrama prikazanih na slikama 1 i 2 , može se konstatovati da su uzorci siromašne rude finozrniji u odnosu na uzorke istih proizvoda bogate rude bakra, što može navesti na zaključak o manjoj otpornosti prema usitnjavanja siromašne $u$ odnosu na bogatu rudu bakra. Ova pretpostavka je u suprotnosti sa dosadašnjim teorijskim i praktičnim saznanjima o ovim sirovinama, što je predstavljalo osnovni motiv za dalja istraživanja.
Bond-ova teorija usitnjavanja je široko prihvaćena $\mathrm{u}$ teoriji $\mathrm{i}$ praksi procesa usitnjavanja prirodnih sirovina. Prema istoj, energija usitnjavnja se definiše primenom relacije:

$$
W=W_{i} \cdot\left(\frac{10}{\sqrt{P}}-\frac{10}{\sqrt{F}}\right),(\mathrm{kWh} / \mathrm{t})
$$

gde su:

$\mathrm{W}$ - specifična potrošnja energije $(\mathrm{kWh} / \mathrm{t})$

$\mathrm{W}_{\mathrm{i}}$ - Bond-ov radni indeks meljivosti sirovine $(\mathrm{kWh} / \mathrm{t})$

F - veličina otvora sita kroz koje prolazi $80 \%$ sirovine pre usitnjavanja $(\mu \mathrm{m})$

$\mathrm{P}$ - veličina otvora sita kroz koje prolazi $80 \%$ sirovine posle usitnjavanja $(\mu \mathrm{m})$

Bond-ov radni indeks $\left(\mathrm{W}_{\mathrm{i}}\right)$, je materijalna konstanta koja se utvrđuje laboratorijskim ispitivanjima po proceduri $\mathrm{i} u$ uređaju koji je definisao F.C. Bond, [Bond, 1949; 1952; 1961].

Kao metod za određivanje Bond-ovog radnog indeksa meljivosti, u ovom radu, korišćen je skraćeni postupak, prof. N. Magdalinovića [N. Magdalinović, 1985; 1989].

\subsection{Uticaj granulometrijskog sastava polaznog uzorka klase krupnoće - 3,35 mm, na vrednost Bond-ovog radnog indeksa meljivosti}

Primenom jednačine (1), uz zadate vrednosti parametara, $\mathrm{m},(\mathrm{m}=0,2 ; 0,4 ; 0,6 ; 0,8$; $1,0)$, definisani su granulometrijski sastavi, sintetički formiranih, polaznih uzoraka siromašne i bogate rude bakra za određivanje Bond-ovog radnog indeksa meljivosti. Kumulativne i parcijalne vrednosti učešća pojedinih klasa krupnoće za formiranje sintetičkih uzoraka date su u tabeli 1, a krive granulometrijskih sastava istih uzoraka dijagramima su prikazane na slici 3 . 
Tabela 1. Granulometrijski sastav sintetičkih polaznih uzoraka siromašne i bogate rude bakra

\begin{tabular}{|c|c|c|c|c|c|}
\hline \multirow{3}{*}{$\begin{array}{l}\text { Veličina otvora sita } \\
\text { d (mm) }\end{array}$} & \multicolumn{5}{|c|}{$\mathbf{m}$} \\
\hline & 0,2 & 0,4 & 0,6 & $\mathbf{0 , 8}$ & 1,0 \\
\hline & \multicolumn{5}{|c|}{ Kumulativni prosev sita $\mathrm{D}=100\left(\mathrm{~d} / \mathrm{d}_{\max }\right)^{\mathrm{m}}(\%)$} \\
\hline$-3,350+1,700$ & 100,00 & 100,00 & 100,00 & 100,00 & 100,00 \\
\hline$-1,700+0,850$ & 87,31 & 76,24 & 66,56 & 58,12 & 50,75 \\
\hline$-0,850+0,425$ & 76,01 & 57,78 & 43,92 & 33,38 & 25,37 \\
\hline$-0,425+0,150$ & 66,17 & 43,79 & 28,97 & 19,17 & 12,69 \\
\hline$-0,150+0,106$ & 53,73 & 28,87 & 15,51 & 8,33 & 4,48 \\
\hline$-0,106+0,075$ & 50,12 & 25,12 & 12,59 & 6,31 & 3,16 \\
\hline$-0,075+0$ & 46,77 & 21,88 & 10,23 & 4,79 & 2,24 \\
\hline Klasa krupnoće (mm) & \multicolumn{5}{|c|}{ Parcijalno učešće klasa krupnoće W (\%) } \\
\hline$-3,350+1,700$ & 12,69 & 23,76 & 33,44 & 41,88 & 49,25 \\
\hline$-1,700+0,850$ & 11,30 & 18,46 & 22,65 & 24,74 & 25,37 \\
\hline$-0,850+0,425$ & 9,84 & 13,99 & 14,94 & 14,21 & 12,69 \\
\hline$-0,425+0,150$ & 12,45 & 14,92 & 13,46 & 10,84 & 8,21 \\
\hline$-0,150+0,106$ & 3,60 & 3,74 & 2,92 & 2,02 & 1,31 \\
\hline$-0,106+0,075$ & 3,35 & 3,25 & 2,36 & 1,52 & 0,93 \\
\hline$-0,075+0$ & 46,77 & 21,88 & 10,23 & 4,79 & 2,24 \\
\hline
\end{tabular}

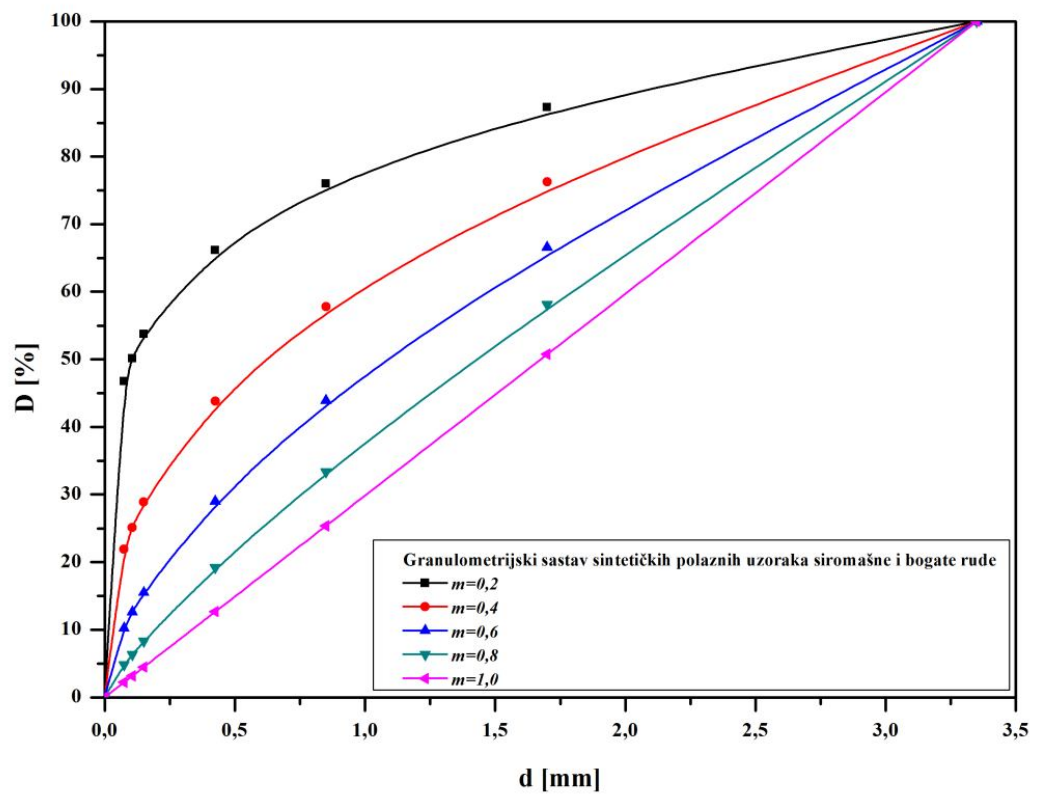

Sl. 3. Krive granulometrijskih sastava sintetičkih polaznih uzoraka siromašne i bogate rude bakra 
Rezultati ispitivanja Bond-ovog radnog indeksa meljivosti primenom skraćenog postupka prof. N. Magdalinovića, na sintetički formiranim polaznim uzor- cima siromašne rude bakra prikazani su u tabeli 2, a isti pokazatelji dobijeni na sintetičkim uzorcima bogate rude dati su u tabeli 3 .

Tabela 2. Bond-ov radni indeks meljivosti siromašne rude bakra u funkciji parametra $m$

\begin{tabular}{|c|r|r|r|r|r|}
\hline \multirow{2}{*}{ Parametri } & \multicolumn{5}{|c|}{$\mathbf{m}$} \\
\cline { 2 - 6 } & \multicolumn{1}{|c|}{$\mathbf{0 , 2}$} & \multicolumn{1}{|c|}{$\mathbf{0 , 4}$} & \multicolumn{1}{c|}{$\mathbf{0 , 6}$} & \multicolumn{1}{c|}{$\mathbf{0 , 8}$} & \multicolumn{1}{c|}{$\mathbf{1 , 0}$} \\
\hline Pc $(\boldsymbol{\mu m})$ & 106,00 & 106,00 & 106,00 & 106,00 & 106,00 \\
\hline $\mathbf{G}(\mathbf{g})$ & 1,60 & 1,32 & 1,13 & 1,07 & 1,16 \\
\hline $\mathbf{P}(\boldsymbol{\mu} \mathbf{m})$ & 69,8 & 82,8 & 83,1 & 86,0 & 75,0 \\
\hline $\mathbf{F}(\boldsymbol{\mu m})$ & 1172,2 & 2008,9 & 2373,8 & 2560,7 & 2677,6 \\
\hline $\mathbf{W i}(\mathbf{k W h} / \mathbf{t})$ & $\mathbf{1 2 , 5 9}$ & $\mathbf{1 5 , 2 4}$ & $\mathbf{1 7 , 0 1}$ & $\mathbf{1 7 , 9 9}$ & $\mathbf{1 5 , 4 7}$ \\
\hline
\end{tabular}

Tabela 3. Bond-ov radni indeks meljivosti bogate rude bakra u funkciji parametra $m$

\begin{tabular}{|c|r|r|r|r|r|}
\hline \multirow{2}{*}{ Parametri } & \multicolumn{5}{|c|}{$\mathbf{m}$} \\
\cline { 2 - 6 } & \multicolumn{1}{|c|}{$\mathbf{0 , 2}$} & \multicolumn{1}{|c|}{$\mathbf{0 , 4}$} & \multicolumn{1}{c|}{$\mathbf{0 , 6}$} & \multicolumn{1}{c|}{$\mathbf{0 , 8}$} & \multicolumn{1}{c|}{$\mathbf{1 , 0}$} \\
\hline $\mathbf{P c}(\boldsymbol{\mu m})$ & 106,00 & 106,00 & 106,00 & 106,00 & 106,00 \\
\hline $\mathbf{G}(\mathbf{g})$ & 2,09 & 1,72 & 1,44 & 1,30 & 1,64 \\
\hline $\mathbf{P}(\boldsymbol{\mu m})$ & 76,0 & 77,0 & 78,5 & 78,5 & 77,0 \\
\hline $\mathbf{F}(\boldsymbol{\mu m})$ & 1172,2 & 2008,9 & 2373,8 & 2677,6 & 2560,7 \\
\hline $\mathbf{W i}(\mathbf{k W h} / \mathbf{t})$ & $\mathbf{1 0 , 7 0}$ & $\mathbf{1 1 , 7 1}$ & $\mathbf{1 3 , 4 8}$ & $\mathbf{1 4 , 4 7}$ & $\mathbf{1 1 , 8 3}$ \\
\hline
\end{tabular}

Dobijene vrednosti Bond-ovog radnog indeksa meljivosti, kako za siromašnu, tako i bogatu rudu bakra, nedvosmisleno ukazuju da granulometrijski sastav polaznog uzorka klase krupnoće $-3,35 \mathrm{~mm}$ definisan preko koeficijenta pravca $\mathrm{m}$, utiče na vrednost pokazatelja otpornosti prema usitnjavanju.

Razlike u vrednosti Bond-ovog radnog indeksa meljivosti, za siromašnu rudu bakra, od 5,4 kWh/t, i bogatu rudu bakra od 3,77 $\mathrm{kWh} / \mathrm{t}$, su sa stanovišta kako teorije usitnjavanja tako i praktične primene respektabilne i treba ih uvažavati.

Svi eksperimenti potvrđuju da pri istim granulometrijskim sastavima polaznih uzoraka klase krupnoće $-3,35 \mathrm{~mm}$ za određi- vanje Bond-ovog radnog indeksa, siromašne rude imaju veću vrednost otpornosti prema usitnjavanju u odnosu na bogate rude bakra, što je u skladu sa dosadašnjim, kako teorijskim tako i praktičnim iskustvima na ovim sirovinama.

\subsection{Zavisnost Bond-ovog radnog indeksa meljivosti od koeficijenta pravca krive granulometrijskog sastava, m, polaz- nog uzorka klase krupnoće - 3,35 mm}

Rezultati istraživanja na sintetičkim uzorcima siromašne i bogate rude bakra, klase krupnoće $-3,35 \mathrm{~mm}$, prikazani su dijagramima na slici 4 . 


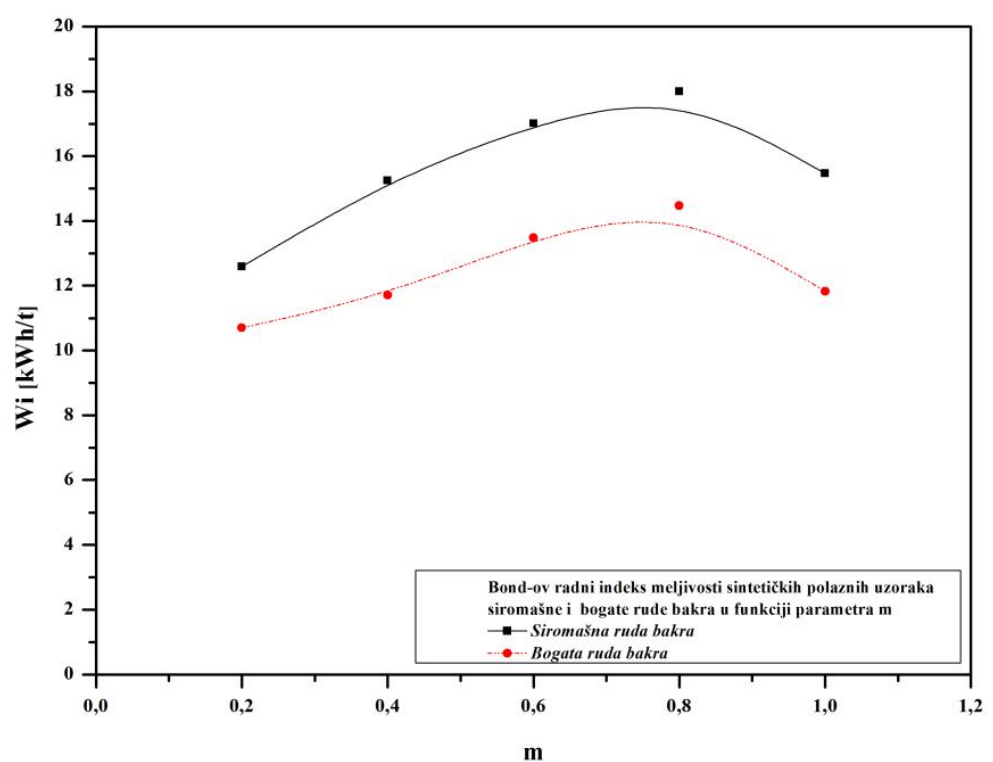

S1. 4. Zavisnost Bond-ovog radnog indeksa meljivosti od koeficijenta pravca krivih granulometrijskih sastava, m, polaznog uzorka klase krupnoće $-3,35 \mathrm{~mm}$

Analizom rezultata istraživanja mogu se konstatovati dve činjenice. Sve vrednosti Bond-ovog radnog indeksa meljivosti za siromašnu rudu bakra su veće u odnosu na isti pokazatelj za bogatu rudu bakra istih granulometrijskih karakteristika. Takođe, potvrđuje se zavisnost Bond-ovog radnog indeksa od granulometrijskog sastava početnog uzorka klase krupnoće - 3,35 mm, predstavljenog preko koeficijenta pravca krivih granulometrijskih sastava, $\mathrm{m}$.

Funkcionalna zavisnost navedenih pokazatelja za siromašnu i bogatu rudu bakra ima sličan trend.

\section{ZAKLJUČAK}

Oblik i forma pojavljivanja u ležištu, miniranje i način eksploatacije kao i primarno usitnjavanje sirovine $\mathrm{u}$ različitim uslovima mogu usloviti da sirovine otpornije prema usitnjavanju imaju finozrniji granulometrijski sastav od sirovina sa manjom otpornošću.
Relativno selektivno usitnjavanje sirovine u laboratorijskim drobilicama pri formiranju uzoraka klase krupnoće -3,35 $\mathrm{mm}$, za određivanje Bond-ovog radnog indeksa meljivosti ne retko, navedenu pojavu ne može promeniti, tako da i početni uzorak za određivanje pokazatelja otpornosti prema usitnjavanju, ima neadekvatan granulometrijski sastav. Istraživanja na siromašnoj i bogatoj rudi bakra RTB - Bor ovu konstataciju potvrđuju.

Istraživanja Bond-ovog radnog indeksa meljivosti za siromašnu i bogatu rudu bakra, primenom metode skraćenog postupka prof. Magdalinovića [Magdalinović, 1989] (tabela 2 i 3), ukazuju da granulometrijski sastav početnog uzorka $-3,35 \mathrm{~mm}$, utiče na vrednost ovog pokazatelja meljivosti. Zavisnost Bond-ovog radnog indeksa meljivosti od granulometrijskog sastava početnog uzorka, predstavljenog preko koeficijenta pravca, m, prikazana je dijagramima na slici 4. Razlike u vrednostima 


\section{LITERATURA}

Bond-ovog radnog indeksa meljivosti, za siromašnu rudu bakra od $5,4 \mathrm{kWh} / \mathrm{t}$, odnosno cca $42 \%$, i bogatu rudu bakra od $3,77 \mathrm{kWh} / \mathrm{t}$, odnosno cca $35 \%$, su sa stanovišta kako teorije tako i praktične primene respektabilne i treba ih uvažavati.

Svi opiti potvrđuju da pri istim granulometrijskim sastavima, istim koeficijentima pravaca, m, početnih uzoraka klase krupnoće $-3,35 \mathrm{~mm}$ za određivanje Bondovog radnog indeksa meljivosti, siromašne rude imaju veću otpornost prema usitnjavanju u odnosu na isti pokazatelj za bogatu rudu bakra.

Funkcionalne zavisnosti Bond-ovog radnog indeksa meljivosti od koeficijenata pravaca krivih granulometrijskih sastava kako siromašne tako i bogate rude bakra imaju sličan trend. U budućim istraživanjima na više različitih sirovina sagledaće se mogućnost definisanja modela navedenih funkcionalnih zavisnosti.
[1] R. Stanojlović, J. Sokolović, N. Stančev, Granulometrijski sastav polaznog uzorka klase krupnoće -3,35 mm faktor pouzdanosti Bond-ovog radnog indeksa meljivosti, Rudarski radovi, 1 (2013), str. 161-170.

[2] N. Magdalinović, Usitnjavanje i klasiranje mineralnih sirovina, Praktikum, Tehnički fakultet u Boru, Bor, 1985.

[3] N. Magdalinović, A procedure for rapid determination of the Bond work index, International Journal of Mineral Processing, 27 (1-2) (1989), str. 125132.

[4] N. Magdalinović, Energija usitnjavanja, Tehnički fakultet u Boru, Bor, 1992.

[5] F. C. Bond, Standard grindability test tabulated, Trans. Am. Inst. Min. Eng., 183 (1949), str. 313-329.

[6] F. C. Bond, The third theory of communition, Trans. Am. Inst. Min. Eng., 193, (1952), str. 484-494.

[7] F. C. Bond, 1961., Crushing and grinding calculations part I and II, British Chemical Engineering 6 (6 and 8), 1961. 